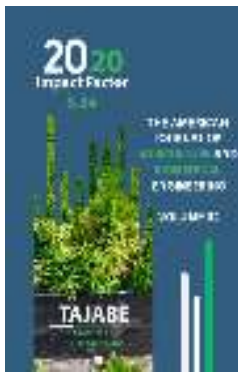

Journal Website: http://usajournalshub.c om/index,php/tajabe

Copyright: Original content from this work may be used under the terms of the creative commons attributes 4.0 licence.

\section{Positive Effect Of Mineral Nutrition On The Quantity Of Vitamins And Chemical Content Of Stevia (Stevia Rebaudiana Bertoni)}

\author{
A.Y. Ulugboev \\ Doctoral Student Of Cotton Breeding, Seed Production And Agro-Technologies Research \\ Institute, Uzbekistan
}

\author{
A.A. Kurbanov \\ Assistant Of Tashkent State Agrarian University, Uzbekistan \\ S.Sh. Khayrullaev \\ Assistant Of Tashkent State Agrarian University, Uzbekistan
}

\title{
ABSTRACT
}

In recent years, all over the world, special attention is paid to plants with sweet taste, but not having a negative effect on human health. In developed countries, 6-7\% of stevia side is obtained from stevia leaves, which have a sweet honey taste. Which are widely used in confectionery farms. Stevia extracts are over 300 times sweeter than sugar. Also, in the composition in the leaves of stevia contains vitamin C, B1, B2, PP, which is very important for human health. In the experiment, comparatively high indicators for the content of vitamin "B2" $36.0 \mathrm{mg} / 100 \mathrm{~g}$ were noted when using mineral fertilizers in N50 P175 K50. In agriculture, improving and maintaining the quality of products is one of the main tasks. In this regard, all field trials require the study of product quality. In Stevia, the quality of the food depends to a certain extent on the chemical composition of the plants. That is, the content of mineral substances and vitamins in the plant.

It has been established that the use of mineral fertilizers increases the content of phosphorus, iron, calcium and other mineral substances. In the experiment, comparatively low values for the iron content of $4.9 \mathrm{mg} / 100 \mathrm{~g}$ were observed in the control variant without the use of mineral fertilizers. In the variants of the applied mineral fertilizers, the iron content in stevia was $5.1-6.0 \mathrm{mg} / 100 \mathrm{~g}$. The highest iron content in the stevia composition, $6.0 \mathrm{mg} / 100 \mathrm{~g}$, was noted in the variant with the use of mineral fertilizers at the rate of $\mathrm{N} 50 \mathrm{P} 175 \mathrm{~K} 50 \mathrm{~kg} / \mathrm{ha}$.

\section{KEYWORDS}

Stevia, stivioside, succharose, minerals, vitamins, variant, experiment, leaf, yield, phosphorus, mineral nutrition, medicinal plant, chemical composition, mineral fertilizers, calcium, nitrogen, phosphorus, potassium, iron, physiological process, yield. 


\section{INTRODUCTION}

There is a great demand in the world today for the use of natural plant sources that give a sweet taste and do not harm human health. In developed countries, the 6-7\% stivioside sweet substance in stevia leaf has been widely used for several years in the preparation of confectionery products, various beverages, canned goods and as a medicine. Stevia extract is about 300 times sweeter than cane sugar and succharose.

Stevia leaves also contain vitamins $C, B_{1}, B_{2}, P P$, which are very important in human health. In the experiment, the highest content of vitamin $B_{2}$ in stevia was recorded in the variant $N_{50} P_{175}$ $\mathrm{K}_{50}$ with a high content of $36.0 \mathrm{mg} / 100 \mathrm{~g}$ of mineral fertilizers.

Maintaining and improving product quality in the cultivation of agricultural crops is one of the most main tasks. Due to this, the study of product quality is required in all scientific works.

The quality of the product in the stevia crop depends primarily on the chemical composition of the plant, the presence of minerals and vitamins in the plant and their amount.

In the experimental control variant, the amount of iron in stevia was $4.9 \mathrm{mg} / 100 \mathrm{~g}$. In the variants using mineral fertilizers, the amount of iron in the plant was 5.1-6.0 mg / 100 g. The highest value of iron content in stevia was recorded under the conditions of application of $6.0 \mathrm{mg} / 100 \mathrm{~g}$ of mineral fertilizers $\mathrm{N}_{50} \mathrm{P}_{175} \mathrm{~K}_{50}$. In this variant, the difference from control was $0.2-1.1 \mathrm{mg} / 100 \mathrm{~g}$.

\section{LITERATURE REVIEW}

In our country, the problem of creating conditions for the production of food products, especially products enriched with essential micronutrients, meeting the needs of the population for healthy eating, the provision of food and other medicinal products based on local raw materials is growing. In solving this problem, it is important to adapt the unconventional introduction of plants in our country to climate and agriculture.

One of such crop is the stevia plant. Stevia is one of the crops that adapts to the external environment and grows well in temperate climates.

Currently, more than 15 countries are breeding S. rebaudiana, which is widely used in confectionery, sweet drinks, dietary foods, canned food and medicine. Especially in the USA, England, France, Japan, China, South Korea, Canada, Russia, Ukraine and others, stivia is grown in large areas $[1,3,5]$.

Preliminary research on the cultivation of stevia in the conditions of the Republic, Yu. Uzakov, Yu. Kim, T.M.Duseynov, T.K.Duseynov, I.Belolipov, J.Tursinov, B. It has been studied in the scientific works of such a scientist as Baykabilov. The scientific work mainly studied the morphology, systematics and biological properties of the plant. However, the technology of growing stevia in the conditions of the republic is not sufficiently studied, there is not enough scientific data in this regard. The study of planting stevia in different soil climates, the development of cultivation technology is of great scientific and practical importance $[2,4,10]$.

Maintaining and improving product quality in the cultivation of agricultural crops is one of the most main tasks. Due to this, the study of product quality is required in all scientific works.

The stevia plant is grown for its leaves, so it is advisable to study the leaf quality of stevia in 
practice, as well as the factors that affect leaf quality.

The quality of the product in the stevia crop depends primarily on the chemical content of the plant, the presence of minerals and vitamins in the plant and their amount.

The research work on the product quality of stevia plant, the chemical content of the plant has been studied mainly in foreign countries in the research work of scientists such as P.J.Larkin, T.A.Thorpe, J.K.Yasil, M.J.Aparajta [13]. However, these studies have been conducted in countries such as Europe, Russia, Ukraine, Germany, Poland, Sweden, North America, USA and Canada, and countries in East Asia such as Japan, China and Korea, Australia and New Zealand [6,7,8,9].

Especially in countries such as Japan, China, Korea, the attention to the stevia plant is growing. In Japan, stevia cultivation has risen to the level of national value.

In Uzbekistan, too, in recent years, interest in the stevia plant is growing. In this regard I.Belolipov T.M.Duseynov, T.K.Duseynov, I.Belolipov, J.Tursinov. It has been studied in the scientific works of such a scientist as Baykabilov. The scientific work mainly studied the morphology, systematics and biological properties of the plant. However, the technology of growing stevia in the conditions of the republic is not sufficiently studied, there is insufficient scientific data in this regard [11,12].

\section{EXPERIMENTAL CONDITIONS AND METHOD}

The experiment was conducted in Uychi district of Namangan region. The experimental field consists of meadow-sierozem soils, moderately sandy mechanical composition, irrigated from ancient times, not saline. The driving layer is $0-30$ and $0-40 \mathrm{~cm}$, in some places there is a layer of sand at a depth of $60-70 \mathrm{~cm}$ below the driving layer. Field experiments were carried out according to B.A.Dospekhov's (1982) "Methods of conducting field experiments."

The second field experiment consisted of 4 variants and was conducted in four repetitions. All returns were placed in one tier. All phenological observations and accountings were carried out in the calculated areas of each variant, in separate plants.

The leaf level of a separate plant of stevia and the total leaf level per hectare are determined by the method of A.A.Nichiparovich, the index of biological productivity is determined by the method of I.S.Shatilov, M.K.Kayumov.

\section{EXPERIMENTAL RESULTS}

The amount of vitamins in the leaves of stevia. It is known that the stevia plant is rich in minerals and vitamins. Stevia plant is distinguished by the presence of vitamins $C, B_{1}$, $B_{2}$, PP in the leaves.

One of the important quality indicators of stevia is the amount of vitamins in the leaves. The effect of mineral nutrition on the amount of vitamins in the leaves of stevia in the experiment is shown in Table 1. 
Table 1

The amount of vitamins in the leaves of stevia

\begin{tabular}{|c|c|c|c|cc|}
\hline \multicolumn{2}{|c}{ № } & \multicolumn{5}{c|}{ Vptions } & C & $\mathrm{B}_{1}$ & $\mathrm{~B}_{2}$ & PP \\
\hline $\mathbf{1}$ & & & & & 3.5 \\
\hline $\mathbf{2}$ & Control & 7.9 & 9.5 & 35.5 & 3.5 \\
\hline 3 & $\mathrm{~N}_{50} \mathrm{P}_{175} \mathrm{~K}_{50}$ & 9.0 & 11.0 & 36.0 & 4.0 \\
\hline \hline 4 & $\mathrm{~N}_{50} \mathrm{P}_{150} \mathrm{~K}_{50}$ & 8.5 & 10.3 & 35.8 & 4.0 \\
\hline
\end{tabular}

The results of experiments showed that mineral nutrition has a positive effect on the amount of vitamins in the leaves of stevia plant.

In the experiment, it was observed that the amount of vitamin $C$ in all variants using mineral fertilizers was higher than in the control variant. In the control variant, the amount of vitamin C was $7.9 \mathrm{mg} / 100 \mathrm{~g}$, while in the variants with mineral fertilizers, the amount of vitamin C was $8.1-9.0 \mathrm{mg} / 100 \mathrm{~g}$. Due to mineral nutrition, the amount of vitamin $\mathrm{C}$ in stevia increased by $0.2-1.1 \mathrm{mg} / 100 \mathrm{~g}$. The highest content of vitamin $C$ in stevia was observed with the use of high doses of $9.0 \mathrm{mg}$ / $100 \mathrm{~g}$ of phosphorus fertilizers $\mathrm{N}_{50} \mathrm{P}_{175} \mathrm{~K}_{50}$.

Mineral nutrition has also been shown to have a positive effect on the amount of vitamin $B_{1}$ in stevia. In the experiment, relatively low levels of vitamin $B_{1}$ in the plant were observed in the control variant without the use of $9.5 \mathrm{mg} / 100$ $\mathrm{g}$ of mineral fertilizers. In the absence of phosphorus fertilizers this figure is $9.8 \mathrm{mg} /$ $100 \mathrm{~g}$, in the presence of mineral fertilizers $N_{50}$ $\mathrm{P}_{150} \mathrm{~K}_{50}$ the content of vitamin $\mathrm{B}_{1}$ in the leaves of stevia is $10.3 \mathrm{mg} / 100 \mathrm{~g}$, and in the presence of mineral fertilizers $N_{50} P_{150} K_{50}$ the content of vitamin $B_{1}$ in the leaves of stevia $11.0 \mathrm{mg} / 100 \mathrm{~g}$.
The results of the experiment showed that due to mineral nutrition, the content of vitamin $B_{1}$ in stevia increased by 0.3-1.5 mg / $100 \mathrm{~g}$.

One of the important features of stevia is the presence of the plant. The presence of vitamin $B_{2}$ is in the diet. In the control variant without mineral fertilizers in the experiment, the content of vitamin $B_{2}$ in the stevia plant was $35.5 \%$. The amount of vitamin $B_{2}$ in stevia in the variants using mineral fertilizers was 35.6-36.0 $\mathrm{mg} / 100 \mathrm{~g}$, due to mineral nutrition, the content of vitamin $B_{2}$ in stevia increased by $0.1-0.5 \mathrm{mg} /$ 100g. In the experiment, the highest content of vitamin $B_{2}$ in stevia was recorded in the variant $\mathrm{N}_{50} \mathrm{P}_{175} \mathrm{~K}_{50}$ with a high content of $36.0 \mathrm{mg} / 100$ $\mathrm{g}$ of mineral fertilizers.

The effectiveness of mineral fertilizers was also observed in the amount of vitamin PP in stevia. In the experimental control, the amount of vitamin PP in stevia was $3.5 \mathrm{mg} / 100 \mathrm{~g}$.

In all variants of mineral fertilizers, the content of vitamin PP in stevia was found to be higher than in the control variant. The highest content of vitamin PP in the stevia plant was recorded when $4.5 \mathrm{mg} / 100 \mathrm{~g}$ of mineral fertilizers were applied in high doses $\mathrm{N}_{50} \mathrm{P}_{175} \mathrm{~K}_{50}$. 
The amount of minerals in the stevia leaf. One of the unique features of the stevia plant is the presence of calcium, phosphorus, magnesium, potassium and iron elements in the leaves of the plant.

Each element in the plant has a positive effect on the course of a specific important biological

Table 2

The amount of minerals in the stevia leaf

\begin{tabular}{|c|cccccc|}
\hline № & Options & \multicolumn{5}{c|}{ Minerals in dry leaf, mg / $100 \mathrm{~g}$} \\
\hline & & calcium & phosphorus & magnesium & potassium & iron \\
\hline $\mathbf{1}$ & Control & 2960 & 501 & 1100 & 1600 & $\mathbf{4 . 9}$ \\
\hline $\mathbf{2}$ & $\mathrm{N}_{50} \mathrm{P}_{175} \mathrm{~K}_{50}$ & 2330 & 600 & 1300 & 1850 & $\mathbf{6 . 0}$ \\
\hline $\mathbf{3}$ & $\mathrm{N}_{50} \mathrm{P}_{150} \mathrm{~K}_{50}$ & 2310 & 550 & 1210 & 1760 & $\mathbf{5 . 5}$ \\
\hline \hline 4 & $\mathrm{~N}_{50} \mathrm{~K}_{50}$ & $\mathbf{2 9 8 5}$ & $\mathbf{5 2 0}$ & $\mathbf{1 1 8 0}$ & $\mathbf{1 7 1 0}$ & $\mathbf{5 . 1}$ \\
\hline
\end{tabular}

The data in the table above showed that mineral nutrition has a positive effect on the amount of minerals in the leaves of the stevia plant.

In the experiment, it was shown that the mineral content in all variants using mineral fertilizers was higher than in the control option without mineral fertilizers.

In the experiment, the lowest value in terms of calcium content of stevia leaf was recorded in the control variant without the use of $2960 \mathrm{mg}$ / $100 \mathrm{~g}$ of mineral fertilizers. Only nitrogen and potassium fertilizers were used, and in the absence of phosphorus fertilizers, the calcium content of the leaves was $2985 \mathrm{mg} / 100 \mathrm{~g}$. Under conditions of normal application of mineral fertilizers $N_{50} P_{150} K_{50}$, the calcium content of stevia leaf was $2310 \mathrm{mg} / 100 \mathrm{~g}$. The highest value for the content of calcium in stevia leaves was observed under conditions and physiological process in the organism. Data on the effect of mineral nutrition on the amount of minerals in the leaves in the experiment are given in Table 2. 
One of the most important macronutrients in plant life is potassium (K). Potassium accelerates the process of metabolism in plant life, increases the immunity of plants to external environmental conditions.

Mineral nutrition has also been shown to have a positive effect on the amount of potassium in the stevia plant. In the control variant without the use of mineral fertilizers in the experiment, the amount of potassium (K) in stevia was 1600 $\mathrm{mg} / 100 \mathrm{~g}$. In the variants using mineral fertilizers, the potassium content of stevia was $1710-1850 \mathrm{mg} / 100 \mathrm{~g}$ according to the variants. Due to mineral nutrition, the amount of potassium (K) in stevia increased by $110-250 \mathrm{mg}$ / $100 \mathrm{~g}$.

Mineral nutrition has been shown to have a positive effect on the amount of iron in stevia. In the experimental control variant, the iron content of stevia was $4.9 \mathrm{mg} / 100 \mathrm{~g}$. In the variants using mineral fertilizers, the amount of iron in the plant was $5.1-6.0 \mathrm{mg} / 100 \mathrm{~g}$. The highest level of iron content in stevia was recorded under the conditions of application of $6.0 \mathrm{mg} / 100 \mathrm{~g}$ of mineral fertilizers $\mathrm{N}_{50} \mathrm{P}_{175} \mathrm{~K}_{50}$. In this variant, the difference from control was $0.2-1.1 \mathrm{mg} / 100 \mathrm{~g}$.

\section{CONCLUSIONS}

Based on the results of the experiment, we can make the following conclusions:

1. Soil moisture is a necessary factor for the plant to grow from seed under the conditions of introduction. The influence of air temperature and humidity is also important in the origin of the species in its natural habitat.

2. Introduced in Namangan region, the shorttime tropical S. rebaudiana has fully passed all stages of ontogenesis. Air temperature affected the onset times of vegetation. It was found that the onset of budding and flowering depends on the reduction of daylight.

3. An increase in the amount of vitamin $C$ in stevia by $0.2-1.1 \mathrm{mg} / 100 \mathrm{~g}$ was noted due to mineral nutrition. The highest content of vitamin C in stevia was observed with the use of high doses of $9.0 \mathrm{mg} / 100 \mathrm{~g}$ of phosphorus fertilizers $\mathrm{N}_{50} \mathrm{P}_{175} \mathrm{~K}_{50}$.

4. In the experiment, the highest content of vitamin $B_{1}$ in stevia was recorded at a dose of $11.0 \mathrm{mg} / 100 \mathrm{~g}$ of mineral fertilizers $\mathrm{N}_{50}$ $\mathrm{P}_{175} \mathrm{~K}_{50}$. Due to mineral nutrition, the content of vitamin $B_{2}$ in stevia increased by 0.1-0.5 mg / 100g. In the experiment, the highest content of vitamin $B_{2}$ in stevia was recorded in the variant $\mathrm{N}_{50} \mathrm{P}_{175} \mathrm{~K}_{50}$ with a high content of $36.0 \mathrm{mg} / 100 \mathrm{~g}$ of mineral fertilizers.

5. Stevia is a plant with a temperate climate, adapted to the external environment, and in the conditions of our country it is possible to grow high quality crops from this crop.

6. In the variants using mineral fertilizers, the amount of phosphorus in stevia was 520 $600 \mathrm{mg} / 100 \mathrm{~g}$. In the experiment, it was noted that due to mineral nutrition, the amount of phosphorus in stevia increased to $10-99 \mathrm{mg} / 100 \mathrm{~g}$.

7. In the variants using mineral fertilizers, the amount of potassium in stevia was 1710$1850 \mathrm{mg} / 100 \mathrm{~g}$ according to the variants. Due to mineral nutrition, the amount of potassium (K) in stevia increased by $110-250$ $\mathrm{mg} / 100 \mathrm{~g}$. In the variants using mineral fertilizers, the amount of iron in the plant was 5.1-6.0 mg / $100 \mathrm{~g}$. The highest level of iron content in stevia was recorded under the conditions of application of $6.0 \mathrm{mg} /$ $100 \mathrm{~g}$ of mineral fertilizers $\mathrm{N}_{50} \mathrm{P}_{175} \mathrm{~K}_{50}$. In this variant, the difference in control option was 0.2-1.1 mg / $100 \mathrm{~g}$. 


\section{REFERENCES}

1. Anishin S.L. Vliyanie ploshchadi pitaniya stevii na urojay suxogo lista $v$ Zapadnoy lesostepi Ukrainy // Vvedenie $\mathrm{v}$ kulturu stevii - istochnika nizkokaloriynogo zamenitelya sahara: Tez. dokl. mejd. konf. - Kiev, 1990. - p. 63-66.

2. Baykabilov B., Belolipov I. Vyrashchivanie stevii (Stevia rebaudiana Bertoni (Hemsl) iz semyan na yuge Uzbekistana // Biologiya - nauka XXI veka: Tez. Dokl. Pushchinskoy shkoly-konf. Molodyx uchenyx. Pushchino, 2003. - P.156-157.

3. Bondarev N.I. Composition and content of steviol-glycosides in terrestrial and subterranean organs Stevia rebaudiana Bertoni and ix dynamics in the study of ontogenesis // Physiology of plants based on phytobiotechnology: Thesis. dokl. Mejdunarodnoy nauchnoy konferentsii. Penza, 2003. - p. 379.

4. Duseynov T.K., KimYu. M. KimA.S.Rustamova Propagation of stevia by cuttings // Bulletin of Agrarian Science of Uzbekistan, 2001.№1,37-39 p.

5. Zimin M.V. Influence of regulatory factors on biomorphological development of stevii sorts in the conditions TsChR: Author. dis. ... Kand. biol. science. Ramon, 2006. - 23 p.

6. Zubenko V.F., Rogovskiy C.B., Pedos V.P. Vozbuditeli bolezney stevii // Zashchita rast, -1991.-N4.- 18s.

7. Zubenko V.F., Rogovskiy C.B., Chudnovskiy B.D. Stimulation of phytohormones by ingestion of cherenkov stevii and rosta rassady // Dokl. VASXNIL-1991- N2.- S.16-18;

8. Zubenko V.F., Rogovskiy C.B., Chudnovskiy B.D., Shtokal P.P. Influence of chelnkov chelnkov dliny svetovogo dliny na ukorenyaemost $\mathrm{i}$ rost rassady stevii // Fiziologiya i biohimiya kult, rast, 1991, -T.24, N4.-C.407-412;

9. Ilenko I.I. Productivity of autoclonal variants of stevii and qualitative composition of dietary glucose and its lists. K., 1990, p 156.

10. Kim Yu. Talolova E. - Steviya - noviy istochnik saxra // celcokoe khozyastvo Uzbekistana №10. 1991.37-39 c.

11. Tursunov J.Yu., Belolipov I.V., Raximov M, Boykobilov $B$. The main agronomic techniques of growing stevia from seed. Tash DAU Publishing Department, Tashkent - 2002.

12. Uzakov Yu, Kim Yu, M.Duseynov. Technology of stevia cultivation. Recommendation -T. "Labor" 1994 pages 2-9.

13. Grammer V, Ikan R., Sweet glycosides from the stevia plant. J. Chem. Brit. 1986 